\title{
Ammonium Sulfate Addition Reduces the Need for Guanidinium Isothiocyanate in the Denaturing Transport Medium Used for SARS- COV-2 RNA Detection
}

1 Ge Liu ${ }^{1}$, Jiaoyan Jia ${ }^{2}$, Jianfeng Zhong ${ }^{2}$, Hanfang Jiang ${ }^{3}$, Yongqi Yang ${ }^{2}$, Xiujing Lu* ${ }^{4}$, Zhendan

$2 \mathrm{He}^{1 *}$, Qinchang Zhu ${ }^{1,2} *$

3

4

${ }^{1}$ College of Pharmacy, Shenzhen Technology University, Shenzhen, 518118, PR China

${ }^{2}$ School of Pharmaceutical Sciences, Shenzhen University, Shenzhen, 518060, PR China

${ }^{3}$ Clinical Laboratory, Shenzhen Children's Hospital, Shenzhen, 518038, PR China

${ }^{4}$ GBCBIO Technologies Inc., Guangzhou, 511434, PR China

\section{* Correspondence:}

Xiujing Lu: Email: lu3002@163.com ; Zhendan He: Email: hezhendan@sztu.edu.cn ;

Qinchang Zhu: Email: zhuqc@szu.edu.cn

\section{Abstract}

Rapid identification of SARS-CoV-2 infected individuals through viral RNA detection followed by effective personal isolation remains the most effective way to prevent the spread of this virus. Largescale RNA detection involves mass specimen collection and transportation. For biosafety reasons, denaturing viral transport medium has been extensively used during the pandemic. But the high concentrations of guanidinium isothiocyanate (GITC) in such media have raised issues around sufficient GITC supply and laboratory safety. Here, we tested whether supplementing media containing low concentrations of GITC with ammonium sulfate (AS) would affect the throat-swab detection of SARS-CoV-2 pseudovirus or a viral inactivation assay targeting both enveloped and non-enveloped viruses. Adding AS to the denaturing transport media reduced the need for high levels of GITC and improved SARS-COV-2 RNA detection without compromising virus inactivation.

Keywords: COVID-19, RNA detection, denaturing transport media, guanidinium isothiocyanate, ammonium sulfate 
medRxiv preprint doi: https://doi.org/10.1101/2022.02.28.22271591; this version posted March 2, 2022. The copyright holder for this preprint

(which was not certified by peer review) is the author/funder, who has granted medRxiv a license to display the preprint in perpetuity.

All rights reserved. No reuse allowe kevithout pernisciptC for SARS-COV-2 Detection

\section{Introduction}

34

35

36

37

38

39

40

41

42

43

44

45

46

47

48

49

50

51

52

53

54

55

56

57

58

59

60

61

62

63

64

65

66

67

68

69

70

71

72

73

74

75

76

The ongoing COVID-19 pandemic has resulted in more than 422 million infections and 5.8 million deaths worldwide since its emergence in late 2019 [1, 2]. It appears to have now entered a new wave of infection sparking by the heavily mutated Omicron variant [3]. Although several vaccines (e.g., mRNA vaccines, inactivated vaccines, and viral vector vaccines) have been conditionally approved in some countries $[4,5]$ and various antiviral agents are in various stages of clinical trial $[6,7]$, there is currently no effective way to control the COVID-19 pandemic. Before all susceptible populations are fully protected, it remains extremely important to deal with the pandemic by controlling the infection sources and blocking the transmission routes, both of which rely on rapidly identifying SARS-CoV-2 infected individuals and isolating them from the population. Nucleic acidbased methods are the fastest methods for detecting SARS-CoV-2, especially in the early infection stages [8]. Such methods have played irreplaceable roles in the mass screening for SARS-CoV2 infection. Large-scale nucleic acid testing has been implemented following local case reports where possible community transmission is indicated and this approach has supported China's sustained containment of COVID-19 [9]. Wuhan (Hubei Province) performed city-wide mass screening using reverse-transcriptase quantitative polymerase chain reaction (RT-qPCR) testing for nearly 10 million people over a 10-day period [10], and Qingdao (Shandong Province) tested 10.9 million people for SARS-CoV-2 RNA in 5 days [11].

Large-scale nucleic acid testing involves large-scale specimen collection and transportation. Nasopharyngeal swabs and throat swabs are usually used in the specimen collection for SARS-CoV2 RT-PCR testing [8]. After collection, specimens are generally preserved and transported in nondenaturing or denaturing media. Nondenaturing media, such as conventional viral transport medium and Amies transport medium, mainly contain saline buffer and antibiotics [12-14].

Nondenaturing media are used to maintain the integrity and infectivity of the viruses in the specimen. Therefore, nondenaturing media are used to detect viral nucleic acids and antigens or for culturebased viral detection. However, laboratory personnel risk infection when handling infectious specimens during the testing process, especially during large-scale testing [15]. Denaturing transport media usually contain guanidinium isothiocyanate (GITC) or other virus-inactivating denaturants, which is why they are only suitable for nucleic acid detection. One advantage of denaturing transport medium is its potential to reduce the risk of infection of laboratory personnel and improve SARSCoV-2 RNA detection [16-18]. Both denaturing and nondenaturing viral transport media are widely used [13, 17, 19], and the former are recommended in China for large-scale nucleic acid testing [20]. Although various commercially available and in-house denaturing viral transport media exist, there are no uniform formulation standards. The core component of denaturing viral transport media is usually GITC, whose concentrations are mostly between $30 \%-50 \%(2.5 \mathrm{M}-4.2 \mathrm{M})$ [17]. GITC is a chaotropic agent with a strong protein denaturing function. It is commonly used as a nucleic acid protector during RNA and DNA extraction because it denatures RNases and DNases. GITC is also used to deactivate many viruses including SARS-CoV-2 [17, 21, 22].

However, with the growing demand for denaturing viral transport media in large-scale nucleic acid testing, a GITC supply shortage occurred and its price doubled in early 2021 in China. Therefore, optimizing the formulation by reducing the GITC content may be a way to help meet the demand for SARS-CoV-2 nucleic acid screening and reduce the testing costs. Ammonium sulfate (AS) is a low-cost inorganic salt with high water solubility from its ionic nature. It is often used for protein precipitation and purification in the laboratory. High-concentration AS is also used to 
medRxiv preprint doi: https://doi.org/10.1101/2022.02.28.22271591; this version posted March 2, 2022. The copyright holder for this preprint

enhance RNA stability in tissue samples [23, 24]. Here, we report that reducing the amount of GITC in denaturing viral transport media while adding AS to them can improve the sensitivity of SARSCoV-2 RNA detection without affecting the virus inactivation effect.

\section{$2 \quad$ Materials and methods}

\subsection{Cells and viruses}

Vero cells (ATCC, CCL-81) were cultured in Dulbecco's modified Eagle's medium (Gibco, NY, USA) supplemented with $10 \%$ (v/v) fetal calf serum. SARS-CoV-2 pseudovirus (FNV-2019-nCoVabEN, $>10^{8}$ copies/mL) was purchased from Fubio Biological Technology Co., Ltd. (Hangzhou, China). Herpes simplex virus type 1 (HSV-1, VR-733) originated from the American Type Culture Collection. Enterovirus 71 (EV71, C4 strain) was kindly provided by Dr Tao Peng, Guangzhou Medical University, China. Both HSV-1 and EV71 were propagated and titred in Vero cells. SARSCoV-2 pseudovirus was used directly.

\subsection{Denaturing solutions}

Modified Primestore MTM (Molecular Transport Medium), which we used as a reference medium, contains 3M GITC, $25 \mathrm{mM}$ sodium citrate, $0.5 \%$ SLS (sodium lauryl sulfate) and $20 \mathrm{mM}$ ethylenediaminetetraacetic acid. Basing on the modified Primestore MTM, we prepared the denaturing transport medium with various GITC concentrations and/or AS as indicated.

\subsection{SARS-CoV-2 RNA detection}

A throat swab sample from a healthy person was collected in $4 \mathrm{~mL}$ saline, and the $100 \mu \mathrm{L}$ of SARSCoV-2 pseudovirus ( $>10^{7}$ copies) we added to the sample was mixed in by vortexing. Next, $200 \mu \mathrm{L}$ of the SARS-CoV-2 pseudovirus-containing throat swab sample was added to $1 \mathrm{~mL}$ of each denaturing solution we prepared or to PBS. The solutions were kept at room temperature (RT) or $37^{\circ} \mathrm{C}$, and RNA was extracted from them using the Virus DNA/RNA Kit (GBCBIO) after incubation for $24 \mathrm{~h}, 72 \mathrm{~h}, 120 \mathrm{~h}$ or $5 \mathrm{~d}$. RT $\square$ qPCR detection of SARS-CoV-2 RNA was performed in $20-\mu \mathrm{L}$ reactions.The BeyoFast ${ }^{\mathrm{TM}}$ Probe One-Step qRT-PCR Kit (Beyotime) and primer and probe sequences targeting the ORF1ab gene and $\mathrm{N}$ gene were used in accordance with the protocols for COVID-19 Prevention and Control Guidelines (Seventh Version) issued by China's National Health Commission. The cycle threshold (Ct value) for each sample was recorded and used for cross-sample comparisons. Graphs and statistical analyses (multiple t tests) were prepared with GraphPad Prism 8.0.2 (GraphPad Software, Inc, La Jolla, CA, United States). Statistical significance determined using the Holm-Sidak method, with alpha of 0.01 .

\subsection{Virus inactivation assay}

The viral inactivation abilities of the denaturing solutions containing different GITC concentrations and/or AS were investigated using a plaque reduction assay. HSV-1 virus $\left(100 \mu \mathrm{L}, 4.135 \times 10^{8}\right.$ plaque forming units (PFUs) $/ \mathrm{mL}$ ) or EV71 virus $\left(5 \times 10^{7} \mathrm{PFUs} / \mathrm{mL}\right)$ was added to $0.9 \mathrm{~mL}$ of each denaturing solution, and each solution was mixed and incubated for $1 \mathrm{~h}$ at RT. After incubation, each mixture was serially diluted and filtered through Millex-GP $0.22 \mu \mathrm{m}$ membrane filters (Millipore) and finally used in a plaque reduction assay using previously described procedures $[25,26]$.

\section{$3 \quad$ Results and discussion}

\subsection{Effects of the test solutions on SARS-CoV-2 RNA detection}


medRxiv preprint doi: https://doi.org/10.1101/2022.02.28.22271591; this version posted March 2, 2022. The copyright holder for this preprint (which was not certified by peer review) is the author/funder, who has granted medRxiv a license to display the preprint in perpetuity.

All rights reserved. No reuse allowe Rewithout permissipic for SARS-COV-2 Detection

117 To evaluate the effect of adding AS to denaturing transport media on SARS-CoV-2 RNA detection, a

118 modified commercial denaturing transport medium containing 3M GITC was used as the basic

119

120

121

122

123 formula and reference reagent in the experiments. To mimic the sampling of SARS-CoV-2, a throat swab sample from a healthy person was mixed with SARS-CoV-2 pseudovirus. It was then placed into denaturing media containing different concentrations of GITC and AS and incubated at room temperature or $37^{\circ} \mathrm{C}$ for $24 \mathrm{~h}, 72 \mathrm{~h}, 120 \mathrm{~h}$ or $5 \mathrm{~d}$ as indicated. After RNA extraction, qRT-PCR on the SARS-CoV-2 ORF1 ab and $\mathrm{N}$ genes was performed and comparatively analysed.

The results showed that reducing the GITC concentrations increased the $\mathrm{Ct}$ values, but adding $1 \mathrm{M}$ AS to the transport media reduced the $\mathrm{Ct}$ values of the ORF1ab gene and the $\mathrm{N}$ gene irrespective of the 24-h, 72-h or 120-h incubation period (Fig. 1A and 1B). A further assay on the samples incubated at RT or $37^{\circ} \mathrm{C}$ for 5 days revealed that adding $1 \mathrm{M}$ AS to transport media containing lower GITC concentrations significantly reduced the $\mathrm{Ct}$ values when compared with PBS or the transport medium containing 3M GITC $(\mathrm{p}<0.01)$ (Fig. 1C). A clear dose-dependent effect was observed when AS was added to each transport medium containing a fixed GITC concentration (Fig. 1D). Because lower Ct values indicate higher qRT-PCR detection efficiency, these results clearly suggest that adding AS to the transport media can reduce the amount of GITC required for sample denaturation and increase the detection efficiency for SARS-CoV-2 RNA.

GITC is commonly used at high concentrations in denaturing viral transport media [17, 21].

\subsection{Inactivation effects on enveloped and non-enveloped viruses}

147 To compare the virus inactivation effects of denaturing transport media containing low concentrations of GITC and 1M AS with a commonly used denaturing transport medium, a plaque reduction assay designed for enveloped and non-enveloped viruses was performed. SARS-CoV-2 is an enveloped virus. However, the biosafety hazards relating to conducting experiments with a live SARS-CoV-2 virus caused us to use a common enveloped virus, HSV-1, to evaluate the inactivation effect of various transport media against this virus. We also tested EV71, a non-enveloped virus with a typical icosahedral capsid structure. After subjecting the viruses to various denaturing solutions at $\mathrm{RT}$ for $1 \mathrm{~h}$, each virus was subjected to a plaque reduction assay.

160

The results showed that a common denaturing viral transport medium containing 3M GITC completely inactivated both HSV-1 and EV71 (Fig. 2A and 2B). No difference was observed in HSV-1 inactivation when $1 \mathrm{M}$ AS was added to the media even when the GITC concentrations were reduced to $0.1 \mathrm{M}$ (Fig. 2A). In the EV71 inactivation experiments, the effect of supplementing the transport media with $0.5 \mathrm{M}$ GITC plus $1 \mathrm{M}$ AS was equal to that where $3 \mathrm{M}$ GITC was present, and EV71 was completely inactivated (Fig 2B). These results suggest that decreasing the GITC 
medRxiv preprint doi: https://doi.org/10.1101/2022.02.28.22271591; this version posted March 2, 2022. The copyright holder for this preprint

161 concentrations but adding AS to the transport media did not affect the virus inactivation effect when

162 compared with general denaturing transport medium containing GITC at high concentration.

\section{Conclusions}

164 Faced with the ongoing global COVID-19 pandemic, we sought a safer, low-cost denaturing viral

165 transport medium for preserving SARS-CoV-2 RNA without compromising the effectiveness of viral

166 detection. Based on the components of the modified commercial transport medium we used as a

167 reference reagent, we reduced the GITC concentrations in the media, added AS, and obtained a new

168 formula. We tested the different transport media by detecting SARS-CoV-2 pseudovirus in a throat

169 swab sample and via a viral inactivation assay targeting both enveloped and non-enveloped viruses.

170 We found that adding AS to the denaturing transport media reduced the use of GITC, improved

171 SARS-COV-2 RNA detection, and did not compromise the virus inactivation effect of the media.

172 These findings suggest that AS is a potential component that when added to denaturing transport

173 medium may reduce the cost and improve the detection efficiency towards SARS-COV-2 RNA.

\section{Conflict of Interest}

175 Author Xiujing Lu was employed by GBCBIO Technologies Inc.. The remaining authors declare that

176 the research was conducted in the absence of any commercial or financial relationships that could be

177 construed as a potential conflict of interest.

\section{Author Contributions}

179 LG conceived, planned the experiments and wrote the manuscript. JJY, ZJF and YYQ carried out the 180 experiment. JHF analyzed the data and reviewed the manuscript. LXJ, HZD and ZQC conceived the 181 original idea, acquired financial support and supervised the project.

\section{Funding}

183 This project was funded by the Science and Technology Program of Guangdong Province

184 (2018A030313252), the Shenzhen Science and Technology Project (JCYJ20190808122605563), the

185 Shenzhen Peacock Plan and the Fundamental Research Funds for Shenzhen Technology University.

\section{Acknowledgments}

187 We thank Professor Tao Peng of Guangzhou Medical University for providing enterovirus 71. We

188 also thank Dr. Sandra Cheesman for editing the language of a draft of this manuscript.

\section{References}

191 1. Wang, C., et al., A novel coronavirus outbreak of global health concern. Lancet, 2020. 395(10223): p. 470-473.

2. WHO, Weekly epidemiological update on COVID-19 - 22-February-2022. https://www.who.int/publications/m/item/weekly-epidemiological-update-on-covid-19---22-february-

195

196

197 2022, 2022

3. $\quad$ Callaway, E., Heavily mutated Omicron variant puts scientists on alert. Nature, 2021. 600(7887): p. 21.

198 4. Li, Y., et al., A Comprehensive Review of the Global Efforts on COVID-19 Vaccine Development. ACS 
medRxiv preprint doi: https://doi.org/10.1101/2022.02.28.22271591; this version posted March 2, 2022. The copyright holder for this preprint (which was not certified by peer review) is the author/funder, who has granted medRxiv a license to display the preprint in perpetuity.

199

200

201

202

203

204

205

206

207

208

209

210

211

212

213

214

215

216

217

218

219

220

221

222

223

224

225

226

227

228

229

230

231

232

233

234

235

236

237

238

239

240

241

242

243

244

245

246

247

248

249

250

251

Central Science, 2021. 7(4): p. 512-533.

5. Sharma, O., et al., A Review of the Progress and Challenges of Developing a Vaccine for COVID-19. Front Immunol, 2020. 11: p. 585354.

6. Espano, E., et al., COVID-19 Antiviral and Treatment Candidates: Current Status. Immune Netw, 2021. 21(1): p. e7.

7. Simsek Yavuz, S. and S. Unal, Antiviral treatment of COVID-19. Turk J Med Sci, 2020. 50(SI-1): p. 611-619.

8. Tsang, N.N.Y., et al., Diagnostic performance of different sampling approaches for SARS-CoV-2 RTPCR testing: a systematic review and meta-analysis. The Lancet Infectious Diseases.

9. $\quad \mathrm{Li}, \mathrm{Z}$., et al., Comprehensive large-scale nucleic acid-testing strategies support China's sustained containment of COVID-19. Nature Medicine, 2021. 27(5): p. 740-742.

10. Cao, S., et al., Post-lockdown SARS-CoV-2 nucleic acid screening in nearly ten million residents of Wuhan, China. Nature Communications, 2020. 11(1): p. 5917.

11. Xing, Y., et al., Rapid Response to an Outbreak in Qingdao, China. N Engl J Med, 2020. 383(23): p. e129.

12. Smith, K.P., et al., Large-Scale, In-House Production of Viral Transport Media To Support SARS-CoV2 PCR Testing in a Multihospital Health Care Network during the COVID-19 Pandemic. J Clin Microbiol, 2020. 58(8).

13. Penrod, Y., D. Garcia, and S.T. Dunn, Evaluation of transport media for laboratory detection of SARSCoV-2 in upper respiratory tract swab specimens. J Med Virol, 2021. 93(5): p. 2774-2781.

14. Johnson, F.B., Transport of viral specimens. Clin Microbiol Rev, 1990. 3(2): p. 120-31.

15. Karthik, K., et al., Biosafety Concerns During the Collection, Transportation, and Processing of COVID-19 Samples for Diagnosis. Arch Med Res, 2020. 51(7): p. 623-630.

16. Carvalho, A.F., et al., The use of denaturing solution as collection and transport media to improve SARS-CoV-2 RNA detection and reduce infection of laboratory personnel. Brazilian Journal of Microbiology, 2021. 52(2): p. 531-539.

17. Welch, S.R., et al., Analysis of Inactivation of SARS-CoV-2 by Specimen Transport Media, Nucleic Acid Extraction Reagents, Detergents, and Fixatives. Journal of clinical microbiology, 2020. 58(11): p. e01713-20.

18. Erster, O., et al., Improved sensitivity, safety, and rapidity of COVID-19 tests by replacing viral storage solution with lysis buffer. PLoS One, 2021. 16(3): p. e0249149.

19. van Bockel, D., et al., Evaluation of Commercially Available Viral Transport Medium (VTM) for SARS-CoV-2 Inactivation and Use in Point-of-Care (POC) Testing. Viruses, 2020. 12(11).

20. China, N.H.C.o.t.P.s.R.o., SARS-CoV-2 Nucleic Acid Test Workbook for Medical Institutions (Trial Version 2). http://www.nhc.gov.cn/yzygj/s7659/202012/b89bcd0813da41788688eb14787b3c72.shtml, 2020.

21. Pastorino, B., et al., Evaluation of Chemical Protocols for Inactivating SARS-CoV-2 Infectious Samples. Viruses, 2020. 12(6).

22. Westhaus, S., et al., Evaluation of stability and inactivation methods of SARS-CoV-2 in context of laboratory settings. bioRxiv, 2020: p. 2020.09.11.292581.

23. Daum, L.T., et al., A clinical specimen collection and transport medium for molecular diagnostic and genomic applications. Epidemiol Infect, 2011. 139(11): p. 1764-73.

24. Mutter, G.L., et al., Comparison of frozen and RNALater solid tissue storage methods for use in RNA expression microarrays. BMC Genomics, 2004. 5(1): p. 88.

25. Zhu, Q.C., Y. Wang, and T. Peng, Herpes simplex virus (HSV) immediate-early (IE) promoter-directed reporter system for the screening of antiherpetics targeting the early stage of HSV infection. $\mathrm{J}$ Biomol Screen, 2010. 15(8): p. 1016-20.

26. Zhu, Q.C., et al., Inhibition of enterovirus 71 replication by chrysosplenetin and penduletin. Eur $\mathbf{J}$ Pharm Sci, 2011. 44(3): p. 392-8.

27. Paik, S. and $\mathrm{X}$. Wu, Measuring toxic gases generated from reaction of guanidine isothiocyanatecontaining reagents with bleach. Chemical Health \& Safety, 2005. 12(4): p. 33-38.

28. Allewell, N.M. and A. Sama, The effect of ammonium sulfate on the activity of ribonuclease A. Biochim Biophys Acta, 1974. 341(2): p. 484-8. 
medRxiv preprint doi: https://doi.org/10.1101/2022.02.28.22271591; this version posted March 2, 2022. The copyright holder for this preprint (which was not certified by peer review) is the author/funder, who has granted medRxiv a license to display the preprint in perpetuity.

All rights reserved. No reuse allowe Redithout permissip' $^{2}$ for SARS-COV-2 Detection

29. ES, L., Methods and reagents for preserving RNA in cell and tissue samples. US Patent, 2001 $(6,204,375)$.

Figure 1. Effects of ammonium sulfate (AS) addition to denaturing transport media on SARS-CoV-2 RNA detection. (A) ORF1ab gene detection for various samples in denaturing media or PBS for $24 \mathrm{~h}$, $72 \mathrm{~h}$ and $120 \mathrm{~h}$ at room temperature (RT). (B) $\mathrm{N}$ gene detection for various samples in denaturing media or PBS for $24 \mathrm{~h}, 72 \mathrm{~h}$ and $120 \mathrm{~h}$ at RT. (C) ORF1ab gene detection for various samples in denaturing media or PBS for $5 \mathrm{~d}$ at RT or $37^{\circ} \mathrm{C} .{ }^{* *} \mathrm{p}<0.01$ vs. $3 \mathrm{M}$ GITC group. (D) $\mathrm{N}$ gene detection for various samples in denaturing media across an AS concentration gradient for $72 \mathrm{~h}$ at RT. ${ }^{* *} \mathrm{p}<0.01$ vs. Control group. GITC: guanidinium isothiocyanate. Samples without GITC and AS are the PBS controls.

Figure 2. Effects of denaturing transport media containing low concentrations of guanidinium isothiocyanate (GITC) and ammonium sulfate supplementation on virus inactivation. (A) Plaque assay targeting the enveloped HSV-1 virus. (B) Plaque assay targeting the EV71 non-enveloped virus. Viruses were incubated in PBS or transport media containing the indicated components, followed by plaque assays on Vero cells. Plaques were visualized by crystal violet staining. Left panels: representative plaques. Right bar charts: virus titres calculated from the plaque assays. Data represent the average \pm SD from three independent experiments. 
A

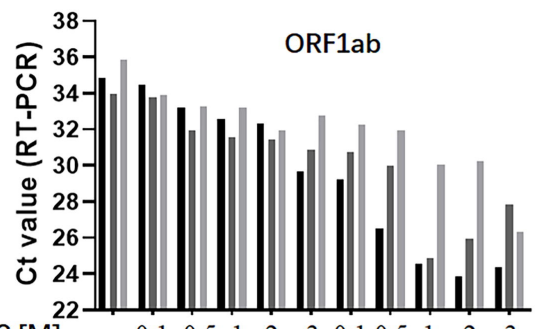

GITC [M]: $-\begin{array}{llllllllll}0.1 & 0.5 & 1 & 2 & 3 & 0.1 & 0.5 & 1 & 2 & 3\end{array}$ AS [1M]: - - - - + + + +

C

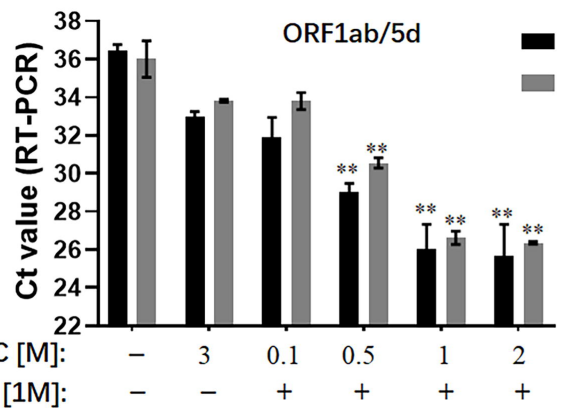

B

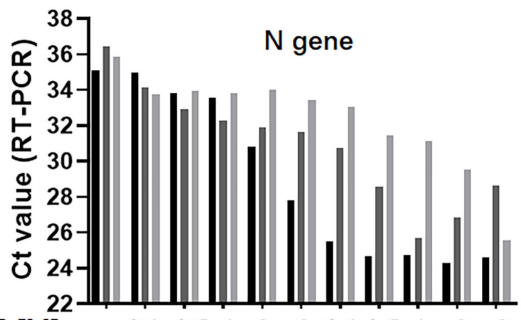

GITC [M]: $\quad-\begin{array}{lllllllllll}0.1 & 0.5 & 1 & 2 & 3 & 0.1 & 0.5 & 1 & 2 & 3\end{array}$ AS [1M]: - $\ldots+\ldots++++$

D

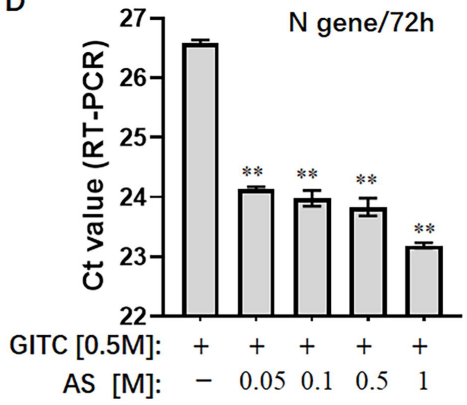


A

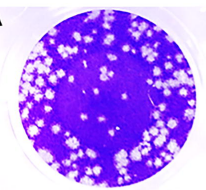

PBS

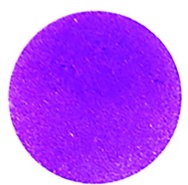

$0.5 \mathrm{M} \mathrm{GITC}+$ AS $1 \mathrm{M} \mathrm{GITC}+$ AS

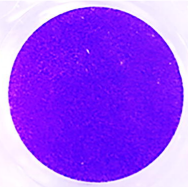

3M GITC

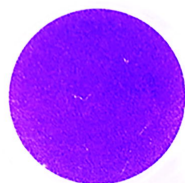

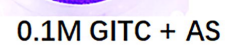

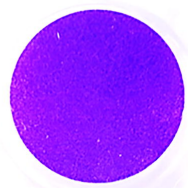

$2 \mathrm{M} \mathrm{GITC}+\mathrm{AS}$

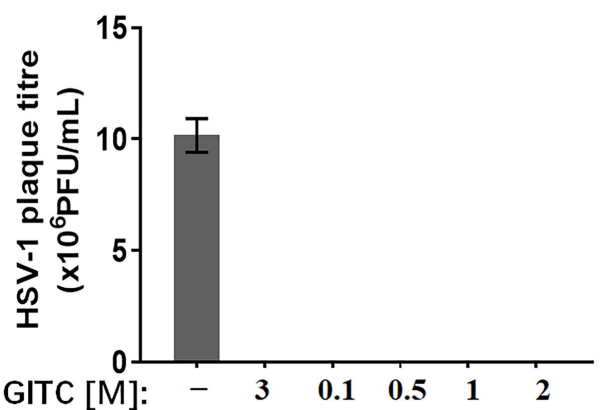

AS [1M]: $\quad-\quad-\quad+\quad+\quad+\quad+$

B

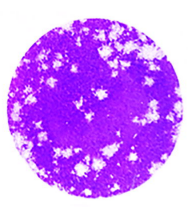

PBS

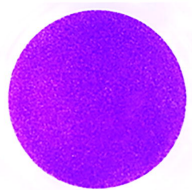

$0.5 \mathrm{M}$ GITC + AS

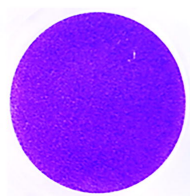

3M GITC

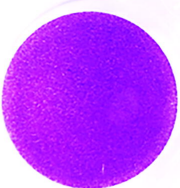

$1 \mathrm{M} \mathrm{GITC}+\mathrm{AS}$

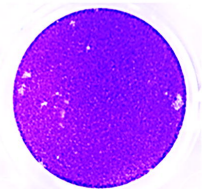

$0.1 \mathrm{M} \mathrm{GITC}+$ AS

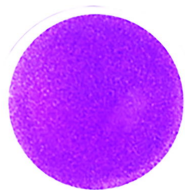

$2 \mathrm{M} \mathrm{GITC}+\mathrm{AS}$

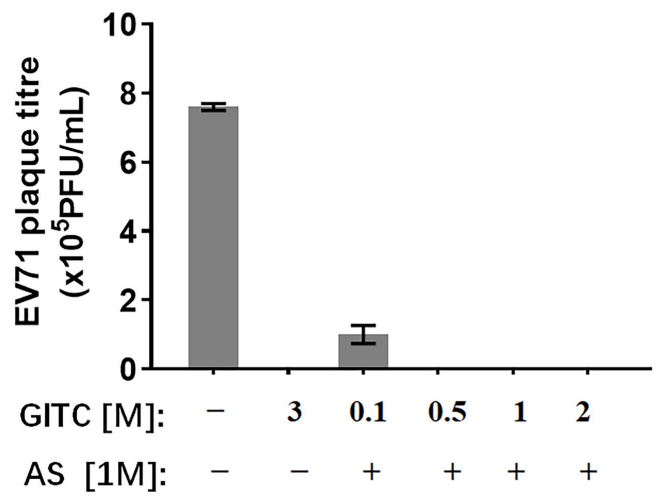

